\title{
EFEKTIVITAS MODEL PEMBELAJARAN TWO STAY TWO STRAY PADA MATERI BILANGAN BERPANGKAT DI SMP AL-WASILAH
}

\author{
Mahsus $^{1}$, Zainuddin'2, Dwi Ivayana Sari ${ }^{3}$ \\ .${ }^{1,2,3}$ Program Studi Pendidikan Matematika, STKIP PGRI Bangkalan \\ Email:mahsusclever@gmail.com
}

\begin{abstract}
Abstrak:
Penelitian ini bertujuan untuk mengetahui kemampuan guru mengelola pembelajaran, respon siswa, ketuntasan belajar siswa dengan model pembelajaran two stay two stray pada materi bilangan berpangkat di SMP Al-wasilah. Jenis penelitian yang digunakan yaitu deskriptif kuantitatif. Sampel yang digunakan yaitu kelas IX SMP Al-Wasilah. Instrument yang digunakan adalah instrument observasi, angket dan tes. Sementara itu, analisis data menggunakan analisis data kemampuan guru mengelola pembelajaran, analisis data respon siswa dan analisis data tes hasil belajar siswa. Berdasarkan hasil analisis data menunjukkan bahwa hasil analisis data skor rata-rata kemampuan guru mengelola pembelajaran dengan menggunakan model pembelajaran two stay two stray diperoleh sebesar 4,44. Sehingga, diperoleh data tingkat kemampuan guru mengelola pembelajaran berada pada kategori baik. Dengan demikian kemampuan guru mengelola pembelajaran dikatakan efektif. Analisis data skor rata-rata respon positif siswa terhadap model pembelajaran two stay two stray diperoleh sebesar 96,4\%. Sehingga, diperoleh data respon positif siswa berada pada kategori sangat setuju. Dengan demikian respon siswa dikatakan efektif. Hasil persentase ketuntasan belajar siswa secara klasikal diperoleh sebesar $81,25 \%$. Sehingga, data ketuntasan belajar siswa secara klasikal $>80 \%$. Dengan demikian Tes Hasil Belajar siswa dengan model pembelajaran two stay two stray dika dikatakan efektif. Dapat disimpulkan bahwa model pembelajaran two stay two stray efektif.
\end{abstract}

\section{Kata Kunci: Pembelajaran Two Stay Two Stray, Bilangan Berpangkat}

\begin{abstract}
:
This study aims to determine the ability of teachers to manage learning, student responses, student learning completeness with the two stay two stray learning model on the material of rank numbers. The type of research used is descriptive quantitative. The sample used is class IX SMP Al-Wasilah. Data analysis used data analysis on the ability of teachers to manage learning, analysis of student response data and analysis of student learning outcomes test data. Based on the results of data analysis shows that the results of the data analysis of the average score of the ability of teachers to manage learning using the two stay two stray learning model is 4.44 . The data obtained on the level of teacher ability to manage learning is in the good category. Data analysis of the average score of students' positive responses to the two stay two stray learning model was obtained at $96.4 \%$. The positive response data obtained by students are in the category of strongly agree. The results of the percentage of students' learning completeness classically were obtained at $81.25 \%$. Thus, the classical student learning completeness data is $>80 \%$. It can be concluded that the two stay two stray learning model is effective.
\end{abstract}

\section{Keywords: Two Stay Two Stray Learning, Rank Numbers}

\section{Pendahuluan}

Berdasarkan hasil observasi yang dilakukan pada Tanggal 27-28 Februari 2021 di kelas IX SMP AL-Wasilah, sebagian besar siswa masih kurang memberikan perhatian terhadap pembelajaran matematika. Siswa cenderung tidak aktif, bosan dan kurang adanya timbal balik antara siswa dengan siswa maupun siswa dengan guru. Siswa asyik bercanda dan ngobrol sendiri dengan temannya bahkan ada siswa membaca buku selain buku mata pelajarann yang sedang diajarkan. Sehingga mengakibatkan pada hasil belajar matematika siswa rendah. Hal ini dapat dilihat pada hasil ulangan 
matematika dari 16 siswa kelas IX SMP AlWasilah yang tuntas sebanyak 5 siswa dengan 31,25\% dan 11 siswa yang tidak tuntas yakni dibawah KKM sebanyak 68,75 $\%$. Salah satu penyebabnya adalah pelajaran matematika yang diterima siswa kurang begitu menarik, kebanyakan model yang digunakan guru masih bersifat konvensional. Model lama yang pola pembelajarannya masih berpusat pada guru menjadikan pembelajaran membosankan, karena hampir semua kegiatan pembelajaran yang meliputi penjelasan materi, pemberian konsep dan pemecahan masalah adalah menjadi tanggung jawab guru. Hal ini menjadi permasalahan tersendiri bagi sebagian guru di sekolah.

Guru perlu memperhatikan model pembelajaran yang digunakan untuk mencapai tujuan hasil belajar peserta didik tuntas. Sehingga perlu adanya pemilihan model pembelajaran agar mampu memahamkan siswa pada materi matematika. Hal ini, sejalan dengan penelitian yang dilakukan Yusup (2017) yang menyatakan bahwa penggunaan model pembelajaran dapat memberikan efek yang baik untuk meningkatkan hasil belajar matematika siswa. Selanjutnya, menurut Nasution (2017) yang menyatakan bahwa penggunaan model pembelajaran yang sesuai dengan kebutuhan siswa di sekolah dalam proses pembelajaran dapat memberikan kemampuan pemahaman konsep yang baik pada siswa.

Berdasarkan uraian di atas dapat disimpulkan bahwa seorang guru harus mengubah model pembelajaran lama (ekspositori) yang berpusat pada guru. Hal ini sejalan dengan penelitian yang dilakukan Andriani (2019) yang menyatakan bahwa nilai rata-rata kemampuan komonikasi matematis peserta didik yang diajarkan dengan metode pembelajaran lightening the learning climate lebih tinggi dibandingkan dengan metode ekspositori. Hal ini menunjukkan bahwa model pembelajaran lama yang berpusat pada guru kurang efektif digunakan dalam pembelajaran. Dalam penelitian ini peneliti menggunakan model pembelajaran two stay two stray.

Model pembelajaran two stay two stray merupakan tipe dari model pembelajaran kooperatif dengan menggunakan kelompok-kelompok kecil dengan jumlah anggota tiap kelompok 4 siswa. Menurut Huda (2013) model pembelajaran two stay two stray (dua tinggal dua tamu) dapat digunakan dalam semua mata pelajaran dan untuk semua jenjang usia peserta didik. Struktur dua tinggal dua tamu dapat memberi peluang atau kesempatan untuk membagikan hasil temuan dan informasi dengan kelompok lain. Model pembelajaran kooperatif memungkinkan siswa berinteraksi satu dengan yang lain untuk saling membelajarkan (peer tutoring) dan saling mensuport. Selain itu, model ini dapat mendorong kepercayaan dan partisipasi siswa (Maonde, 2015). Model pembelajaran two stay two stray melibatkan siswa secara aktif dalam mengomunikasikan hasil diskusi maupun informasi yang dimiliki antara kelompok yang satu dengan kelompok lainnya. Model pembelajaran ini membuat siswa tidak hanya menjadi lebih mandiri dan tidak bergantung pada guru, tapi juga memberi dorongan atau motivasi untuk berpikir dan berpartisipasi aktif dalam belajar Sulisworo (2014).

$$
\text { Menurut Purnama }
$$

menyatakan bahwa model pembelajaran two stay two stray efektif dalam meningkatkan hasil belajar matematika siswa. Menurut Artaningsih \& Diputra (2018) yang menyatakan bahwa model pembelajaran TS-TS melalui lesson study berpengaruh signifikan terhadap hasil belajar matematika. Menurut Trisnawati (2017) menyatakan bahwa model pembelajaran two stay two stray dengan pendekatan saintifik efektif diterapkan dalam pembelajaran matematika. Menurut Deninsi (2020) yang menyatakan bahwa model pembelajaran kooperatif tipe two stay two stray efektif terhadap kemampuan berfikir kritis matematika siswa kelas 8 SMP Widya Bhakti Ruteng.

Berdasarkan paparan latar belakang diatas, peneliti akan mengadakan penelitian dengan judul "Efektivitas model pembelajaran two stay two stray pada materi bilangan berpangkat di SMP Alwasilah". 


\section{Metode Penelitian}

Jenis penelitian ini termasuk penelitian deskriptif kuantitatif karena teknis analisis data menggunakan statistik deskriptif. Subjek dalam penelitian ini adalah siswa kelas IX SMP Al-Wasilah tahun ajaran 2020/2021, yang berjumlah 16 siswa. Penelitian ini bertempat di SMP AlWasilah Kabupaten Bangkalan. Sedangkan waktu penelitian dilakukan pada semester ganjil tahun ajaran 2020/2021. Instrumen dalam penelitian ini adalah lembar observasi, angket respon siswa dan tes hasil belajar.

Instrumen lembar observasi digunakan untuk mengumpulkan data kemampuan guru mengelola pembelajaran. Observasi dilakukan oleh seorang pengamat selama proses pembelajaran. angket respon siswa digunakan untuk mengumpulkan data tentang respon siswa terhadap pembelajaran dengan model pempelajaran two stay two stray. Instrument berikutnya adalah soal tes hasil belajar siswa untuk mengetahui ketuntasan belajar siswa setelah mengikuti pembelajaran dengan model pempelajaran two stay two stray pada materi bilangan berpangkat.

Setelah data terkumpul dilakukan analisis dengan menggunakan teknis analisis deskriptif. Data tentang kemampuan guru mengelola pembelajaran dianalisis dengan menggunakan statistik deskriptif. Statistik deskriptif yang dipakai adalah dengan skor rata-rata sebagai berikut:

$T K G$ :

skor rata-rata $=\frac{\text { skor yang diperoleh guru }}{\text { jumlah aspek pengamatan }}$

Adapun kategori skor rata-rata tingkat kemampuan guru (TKG) menurut lasmi (2017) dapat dilihat dari Tabel 1 berikut:
Tabel 1 Kategori Tingkat Kemampuan Guru

\begin{tabular}{cc}
\hline $1,00 \leq \mathrm{TKG}<1,5$ & Tidak baik \\
\hline $1,50 \leq \mathrm{TKG}<2,50$ & Kurang baik \\
\hline $2,50 \leq \mathrm{TKG}<3,50$ & Cukup baik \\
\hline $3,50 \leq \mathrm{TKG}<4,50$ & Baik \\
\hline $4,50 \leq \mathrm{TKG}<5,00$ & Sangat baik \\
\hline
\end{tabular}

Kemampuan guru mengelola pembelajaran dikatakan efektif jika ratarata skor hasil pengamatan kemampuan guru berada pada kategori baik atau sangat baik.

Data respon siswa yang diperoleh melalui angket dan dianalisis dengan menggunakan statistik deskriptif dengan rumus:

$\mathrm{P}=\frac{F}{N} \times 100 \%$

Keterangan:

$\mathrm{P} \quad=$ Persentase jawaban responden pada setiap butir pertanyaan

$\mathrm{F} \quad=$ Jumlah frekuensi jawaban positif (YA) responden pada setiap butir pertanyaan

$\mathrm{N}=$ Jumlah maksimal skor tertinggi jawaban responden pada setiap butir pertanyaan.

Skor rata-rata $=\frac{\text { jumlah respon siswa }}{\text { banyaknya butir pertanyaan }}$ Kriteria persentase hasil analisis data dapat dilihat pada Tabel 2 berikut:

Tabel 2. Kriteria Persentase Respon Siswa

\begin{tabular}{cc}
\hline Persentase & Keterangan \\
\hline $0 \%-20 \%$ & Sangat tidak setuju \\
$21 \%-40 \%$ & Tidak setuju \\
$41 \%-60 \%$ & Ragu-ragu \\
$61 \%-80 \%$ & Setuju \\
$81 \%-100 \%$ & Sangat setuju \\
\hline
\end{tabular}

Respon siswa dikatakan efektif jika respon positif siswa berada pada kategori setuju atau sangan setuju.

Tes digunakan untuk memperoleh data hasil belajar siswa. Tes diberikan 
dalam bentuk soal. Nilai akhir siswa diperoleh dengan rumus sebagai berikut :

$\mathrm{NA}=\frac{\text { skor yang diperoleh siswa }}{\text { total skor }} \times 100 \%$

Dengan NA = Nilai Akhir Belajar Siswa

Siswa dinyatakan tuntas belajar

apabila hasil belajar yang diperoleh mencapai nilai $\geq 70$ sesuai dengan kriteria ketuntasan minimal (KKM) di SMP AlWasilah.

Persentase ketuntasan belajar siswa secara klasikal dihitung dengan rumus sebagai berikut :
$\mathrm{P}=\frac{\sum \text { siswa yang tuntas belajar }}{\sum \text { siswa seluruhnya }} \times 100 \%$

Dengan $\mathrm{P}=$ persentase Ketuntasan Belajar Secara Klasikal

Indikator ketuntasan belajar siswa secara klasikal apabila $\geq 80 \%$ dari seluruh siswa dinyatakan tuntas belajar sesuai dengan yang telah ditetapkan di SMP AlWasilah.

\section{Hasil dan Pembahasan}

Hasil pengamatan terhadap kemampuan guru mengelola pembelajaran disajikan pada Tabel 3.

Tabel 3. Rekapitulasi Kemampuan Guru Mengelola Model Pembelajaran

\begin{tabular}{|c|c|c|c|c|c|c|}
\hline \multirow[b]{2}{*}{ No } & \multirow{2}{*}{ Aspek yang diamati } & \multicolumn{5}{|c|}{ Penilaian } \\
\hline & & 1 & 2 & 3 & 4 & 5 \\
\hline 1 & $\begin{array}{l}\text { Guru mengingatkan kembali tentang pembelajaran } \\
\text { sebelumnya }\end{array}$ & & & $\sqrt{ }$ & & \\
\hline & $\begin{array}{l}\text { Guru menyampaikan tujuan pembelajaran kepada } \\
\text { siswa yaitu Siswa dapat menuliskan perkalian bilangan } \\
\text { dalam bentuk perpangkatan, Siswa dapat menentukan }\end{array}$ & & & & $\sqrt{ }$ & \\
\hline 2 & $\begin{array}{l}\text { hasil perpangkatan suatu bilangan, Mengidentifikasi } \\
\text { sifat pemangkatan pada perpangkatan, Menyelesaikan } \\
\text { masalah sehari-hari yang berkaitan dengan penerapan } \\
\text { konsep bilangan berpangkat. }\end{array}$ & & & & & \\
\hline & $\begin{array}{l}\text { Guru memberikan motivasi kepada siswa yaitu dengan } \\
\text { menjelaskan apabila materi ini dipahami dengan baik }\end{array}$ & & & & $\sqrt{ }$ & \\
\hline 3 & $\begin{array}{l}\text { oleh siswa, maka siswa dapat dengan mudah } \\
\text { menyelesaikan soal yang diberikan oleh guru, serta } \\
\text { siswa dapat menerapkan dalam kehidupan sehari-hari. }\end{array}$ & & & & & \\
\hline 4 & $\begin{array}{l}\text { Guru membagi siswa kedalam } 4 \text { kelompok, tiap } \\
\text { kelompok beranggotakan } 4 \text { siswa. }\end{array}$ & & & & & $\sqrt{ }$ \\
\hline 5 & $\begin{array}{l}\text { Guru memberikan tugas dalam kelompok yang } \\
\text { berkaitan dengan bilangan berpangkat. }\end{array}$ & & & & & $\sqrt{ }$ \\
\hline 6 & $\begin{array}{l}\text { Guru meminta siswa untuk mendiskusikan materi } \\
\text { tentang bilangan berpangkat. }\end{array}$ & & & & & $\sqrt{ }$ \\
\hline 7 & Guru mengamati siswa pada saat mereka diskusi. & & & & & $\sqrt{ }$ \\
\hline 8 & $\begin{array}{l}\text { Guru membimbing siswa pada saat mereka berdiskusi } \\
\text { dengan kelomponya. }\end{array}$ & & & & & $\sqrt{ }$ \\
\hline 9 & $\begin{array}{l}\text { Dua siswa bertamu kekelompok lain untuk meminta } \\
\text { informasi terkait bilangan berpangkat. }\end{array}$ & & & & & $\sqrt{ }$ \\
\hline 10 & $\begin{array}{l}\text { Dua siswa tetap tinggal dikelompoknya untuk } \\
\text { membagikan hasil diskusi kelompok kepada kelompok } \\
\text { lain yang bertamu. }\end{array}$ & & & & & $\sqrt{ }$ \\
\hline 11 & $\begin{array}{l}\text { Siswa yang bertamu kembali kekelompok mereka } \\
\text { masing-masing. }\end{array}$ & & & & & $\sqrt{ }$ \\
\hline 12 & $\begin{array}{l}\text { Siswa yang bertamu melaporkan hasil temuan dari } \\
\text { kelompok lain. }\end{array}$ & & & & & $\sqrt{ }$ \\
\hline 13 & $\begin{array}{l}\text { Siswa yang bertamu mencocokkan hasil temuannya } \\
\text { dengan hasil diskusi dalam kelompoknya. }\end{array}$ & & & & & $\sqrt{ }$ \\
\hline
\end{tabular}




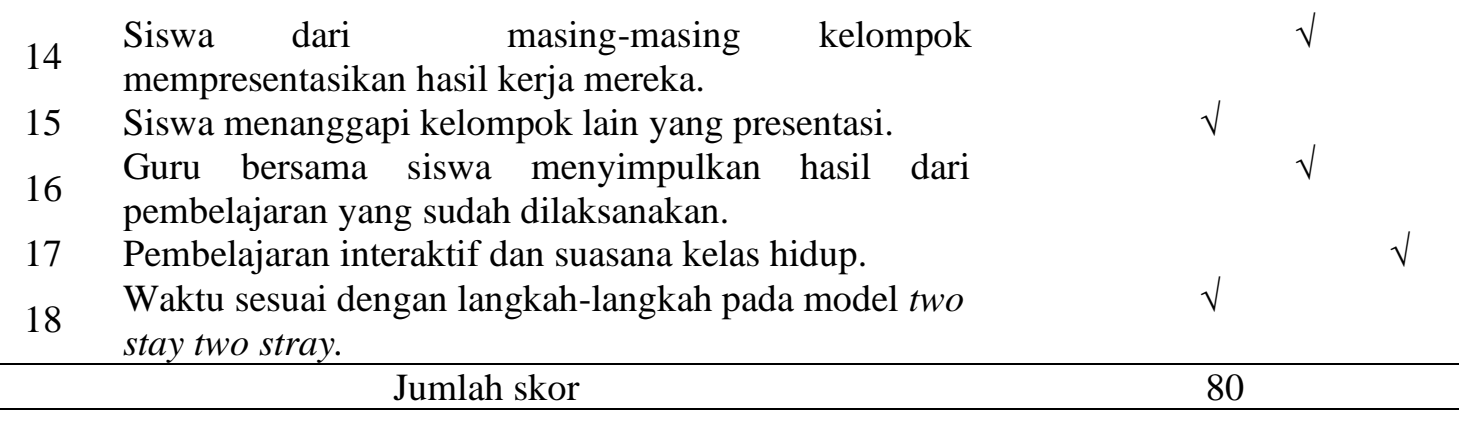

$$
\begin{aligned}
\text { Skor Rata-Rata } & =\frac{\text { skor yang diperoleh }}{\text { jumlah aspek pengamatan }} \\
& =\frac{80}{18} \\
& =4,44
\end{aligned}
$$

Berdasarkan hasil analisis data skor rata-rata kemampuan guru mengelola pembelajaran dengan menggunakan model

\begin{tabular}{|c|c|c|c|c|c|}
\hline \multirow[t]{2}{*}{ No. } & \multirow[t]{2}{*}{ Pernyataan } & \multicolumn{2}{|c|}{$\begin{array}{l}\text { Jumlah } \\
\text { Siswa yang } \\
\text { Menjawab }\end{array}$} & \multicolumn{2}{|c|}{$\begin{array}{c}\text { Persentase } \\
\text { Respon Siswa }\end{array}$} \\
\hline & & $\mathrm{Ya}$ & Tidak & $\mathrm{Ya}$ & Tidak \\
\hline 1. & $\begin{array}{l}\text { Apakah menurutmu model pembelajaran yang } \\
\text { telah digunakan pada hari ini menyenangkan? }\end{array}$ & 16 & - & $100 \%$ & - \\
\hline 2. & $\begin{array}{l}\text { Apakah cara guru menyampaikan materi pada hari } \\
\text { ini lebih menyenangkan dari sebelumnya? }\end{array}$ & 15 & 1 & $93,75 \%$ & $6,25 \%$ \\
\hline 3. & $\begin{array}{l}\text { Apakah dengan model pembelajaran yang } \\
\text { digunakan hari ini suasana belajar dikelasmu lebih } \\
\text { hidup/aktif? }\end{array}$ & 16 & - & $100 \%$ & - \\
\hline 4. & $\begin{array}{l}\text { Apakah kamu merasa lebih memahami materi } \\
\text { apabila menggunakan pembelajaran seperti yang } \\
\text { telah dilakukan hari ini ? }\end{array}$ & 14 & 2 & $87,5 \%$ & $12,5 \%$ \\
\hline 5. & $\begin{array}{l}\text { Apakah menurut pendapatmu pembelajaran hari } \\
\text { ini lebih berarti daripada pembelajaran } \\
\text { sebelumnya? }\end{array}$ & 16 & - & $100 \%$ & - \\
\hline 6. & $\begin{array}{l}\text { Apakah kamu merasa lebih termotivasi untuk } \\
\text { mengikuti pembelajaran dengan menggunakan } \\
\text { model seperti hari ini? }\end{array}$ & 16 & - & $100 \%$ & - \\
\hline 7. & $\begin{array}{l}\text { Apakah kamu berminat mengikuti pembelajaran } \\
\text { berikutnya apabila menggunakan model seperti ini } \\
\text { ? }\end{array}$ & 15 & 1 & $93,75 \%$ & $6,25 \%$ \\
\hline & Jumlah & & & $675 \%$ & $25 \%$ \\
\hline & Skor rata-rata & & & $96,4 \%$ & $3,6 \%$ \\
\hline
\end{tabular}
pembelajaran tipe two stay two stray

\section{Tabel 4. Rekapitulasi Data Respon Siswa}

Hasil analisis data respon siswa sebesar $96,4 \%$ siswa dari 16 siswa merespon positif model pembelajaran two stay two stray. Pembelajaran two stay two stray dinilai sangat baik dan suasana kelas hidup karena siswa belajar dengan cara diperoleh sebesar 4,44, sehingga, diperoleh data tingkat kemampuan guru mengelola pembelajaran berada pada kategori baik. Dengan demikian kemampuan guru mengelola pembelajaran dikatakan efektif.

Hasil data respon siswa dari 16 siswa disajikan pada Tabel 4. 
lebih memahami materi dengan menggunakan model pembelajaran tipe two stay two stray hal ini ditunjukkan dari cara siswa menjawab soal.

Hasil respon siswa menunjukkan respon yang positif bahwa pembelajaran two stay two stray efektif dilakukan jika dilihat dari aspek respon siswa.

Data hasil belajar siswa diperoleh dari hasil tes hasil belajar siswa setelah pembelajaran. Data hasil belajar siswa dapat dilihat pada Tabel 5.

Tabel 5. Data Tes Hasil Belajar

\begin{tabular}{cccc}
\hline No & Nama Siswa & Skor & Keterangan \\
\hline 1 & AR & 73 & Tuntas \\
2 & AS & 92 & Tuntas \\
3 & AN & 90 & Tuntas \\
4 & HU & 88 & Tuntas \\
5 & KH & 84 & Tuntas \\
6 & MI & 52 & Tidak Tuntas \\
7 & MR & 72 & Tuntas \\
8 & MU & 80 & Tuntas \\
9 & MS & 79 & Tuntas \\
10 & MI & 65 & Tidak Tuntas \\
11 & NH & 77 & Tuntas \\
12 & RM & 82 & Tuntas \\
13 & RS & 81 & Tuntas \\
14 & RH & 67 & Tidak Tuntas \\
15 & NA & 76 & Tuntas \\
16 & FI & 75 & Tuntas \\
\hline
\end{tabular}

Berdasarkan Tabel 4 tersebut, kemudian data dirangkum dan dianalisis untuk menentukan persentase ketuntasan klasikal siswa. Data ketuntasan klasikal siswa dapat dilihat pada Tabel 6.

\section{Tabel 6 Data Ketuntasan Klasikal Siswa}

\begin{tabular}{cccc}
\hline No. & Keterangan & Jumlah & Persentase \\
\hline 1 & Tuntas & 13 & $81,25 \%$ \\
\hline 2 & Tidak & 3 & $18,75 \%$ \\
\hline & Tuntas & & \\
\hline
\end{tabular}

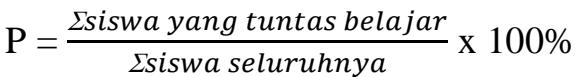

$$
\begin{aligned}
& =\frac{13}{16} \times 100 \% \\
& =81,25 \%
\end{aligned}
$$

Berdasarkan hasil persentase ketuntasan belajar siswa secara klasikal diperoleh sebesar $81,25 \%$. Sehingga data ketuntasan belajar siswa secara klasikal $>80 \%$ maka, dengan demikian model pembelajaran two stay two stray ditinjau dari Tes Hasil Belajar (THB) siswa dikatakan efektif.
Model pembelajaran two stay two stray pada materi bilangan berpangkat ditinjau dari kemampuan guru mengelola pembelajaran, respon siswa dan ketuntasan siswa dikatakan efektif. Karena berdasarkan hasil analisis data, kemampuan guru mengelola pembelajaran, respon siswa berada pada kategori efektif. Sedangkan jika ditinjau dari ketuntasan secara klasikal, sejumlah $81,25 \%$ siswa tuntas belajar.

\section{Simpulan dan Saran}

Model pembelajaran two stay two stray pada materi bilangan berpangkat ditinjau dari kemampuan guru mengelola pembelajaran, respon siswa dan ketuntasan siswa dikatakan efektif karena kemampuan guru mengelola pembelajaran, respon siswa efektif dan mencapai ketuntasan klasikal. Kepada pembaca disarankan agar lebih mengembangkan penelitian ini tidak hanya peninjauan terhadap kemampuan guru mengelola pembelajaran, respon siswa dan ketuntasan secara klasikal saja, akan tetapi bisa ditinjau dari aspek yang lain misalnya aktivitas siswa. 
Daftar Pustaka

Andriani, D. (2019). Pengaruh Model Pembelajaran Lightening The Learning Climate Terhadap Kemampuan Komunikasi Matematis Peserta Didik. Jurnal SIGMA, Volume 5, Nomor 1, September 2019, hlm 22-28.

Arthaningsih, N. K. J., \& Diputra, K. S. (2018). Pengaruh Model Pembelajaran Kooperatif Tipe Two Stay Two Stray Melalui Lesson Study Terhadap Hasil Belajar Matematika. Journal of Education Technology. Vol. 2 (4) pp. 128-136.

Denensi, F. G (2020). Efektivitas Model Pembelajaran Kooperatif Tipe Two Stay-Two Stray Dengan Numbered Heads Together Terhadap Kemampuan Berpikir Kritis Matematika Siswa. Jurnal Ilmiah Pendidikan Matematika Volume 5 Nomor 1 P-ISSN: 2502-7638; EISSN: 2502-8391.

Huda, M. (2013). Cooperative Learning. Yogyakarta : Pustaka Pelajar.

Lasmi. (2017). Penerapan Model Pembelajaran Koperatif Tipe Team Accelerated Instruction (TAI) yang Berorientasi Teori Apos pada Materi Fungsi Kuadrat di Kelas X-MIA MAN 2 Banda Aceh. Jurnal Pendidikan dan Pembelajaran Matematika, 1(1).

Maonde, F. B (2015). The Discrepancy of Students' Mathematic Achievement Through Cooperative Learning Model, and The Ability in Mastering Languages And Science. International Journal of Education and Research, 3(1), 141-158.
Retrieved from

http://ijern.com/journal/2015/Januar $y$-2015/13.pdf

Nadar. (2016). Pengaruh Pendekatan Matematika Realistik, dan Bentuk Portofolio Terhadap Kemampuan Koneksi Matematika. Jurnal Pendidikan Dasar 7(2), hal: 265-282

Nasution, M. K. (2017). Penggunaan Metode Pembelajaran dalam Peningkatan Hasil Belajar Siswa. Jurnal Ilmiah Bidang Pendidikan Vol. 11, No. 1, 2017; ISSN 19788169.

Purnama, K. J. A. (2020). Efektivitas Model Pembelajaran Two Stay Two Stray (TSTS) dalam Meningkatkan Hasil Belajar Matematika. Jurnal Penelitian dan Pengembangan Pendidikan. Vol. 4 (3) pp. 343-350.

Sulisworo, D. (2014). The Effect of Cooperative Learning, Motivation and Information Technology Literacy to Achievement. International Journal of Learning and Development, $\quad 4(2), \quad 58$. https://doi.org/10.5296/ijld.v4i2.4908

Trisnawati, N. F. (2017). Efektivitas Model Pembelajaran Kooperatif Tipe Two Stay Two Stray dengan Pendekatan Saintifik dalam Pembelajaran Matematika pada Siswa SMP Negeri 2 Kota Sorong. Jurnal "Median" Volume IX Nomor 3 Oktober 2017 Hal: 36-42.

Yusup, A. A. M. (2017). Meningkatkan Hasil Belajar Matematika Melalui Penerapan Metode Pembelajaran Kooperatif. Jurnal Formatif 7(2): 124-129, 2017 ISSN: 2088-351X. 